\title{
Loss of Nogo receptor homolog NgR2 alters spine morphology of CA1 neurons and emotionality in adult mice
}

\author{
Sarah C. Borrie ${ }^{1}$, Simone B. Sartori ${ }^{2}$, Julian Lehmann ${ }^{1}$, Anupam Sah ${ }^{2}$, Nicolas Singewald ${ }^{2}$ and \\ Christine E. Bandtlow ${ }^{1 *}$ \\ ${ }^{1}$ Division of Neurobiochemistry, Biocenter, Innsbruck Medical University, Innsbruck, Austria \\ ${ }^{2}$ Department of Pharmacology and Toxicology, Institute of Pharmacy and Centre for Molecular Biosciences Innsbruck, University of Innsbruck, Innsbruck, Austria
}

\section{Edited by:}

Denise Manahan-Vaughan, Ruhr

University Bochum, Germany

Reviewed by:

Martin Korte, Technische

Universitaet Braunschweig,

Germany

Lars Olson, Karolinska Institutet,

Sweden

Roman J. Giger, University of

Michigan School of Medicine, USA

\section{*Correspondence:}

Christine E. Bandtlow, Division of

Neurobiochemistry, Biocenter,

Innsbruck Medical University,

Innrain 80, A-6020 Innsbruck,

Austria

e-mail: christine.bandtlow@

i-med.ac.at
Molecular mechanisms which stabilize dendrites and dendritic spines are essential for regulation of neuronal plasticity in development and adulthood. The class of Nogo receptor proteins, which are critical for restricting neurite outgrowth inhibition signaling, have been shown to have roles in developmental, experience and activity induced plasticity. Here we investigated the role of the Nogo receptor homolog NgR2 in structural plasticity in a transgenic null mutant for NgR2. Using Golgi-Cox staining to analyze morphology, we show that loss of NgR2 alters spine morphology in adult CA1 pyramidal neurons of the hippocampus, significantly increasing mushroom-type spines, without altering dendritic tree complexity. Furthermore, this shift is specific to apical dendrites in distal CA1 stratum radiatum (SR). Behavioral alterations in $\mathrm{NgR2}^{-/-}$mice were investigated using a battery of standardized tests and showed that whilst there were no alterations in learning and memory in $\mathrm{NgR2}^{-/-}$mice compared to littermate controls, $\mathrm{NgR}^{-/-}$displayed reduced fear expression in the contextual conditioned fear test, and exhibited reduced anxiety-and depression-related behaviors. This suggests that the loss of $\mathrm{NgR} 2$ results in a specific phenotype of reduced emotionality. We conclude that NgR2 has role in maintenance of mature spines and may also regulate fear and anxiety-like behaviors.

Keywords: Nogo receptor, NgR2, dendritic spine, hippocampus, anxiety, fear conditioning

\section{INTRODUCTION}

The ability of the brain to remodel, via structural and synaptic plasticity of dendrites and spines, is critical for development of functional circuits, as well as adaptive alterations in adulthood. Experience-dependent remodeling of synaptic connections occurs after the peak of synaptogenesis, during well-defined critical periods of postnatal development (Hensch, 2004). After the end of the critical period, structural plasticity in the adult brain is greatly decreased in response to experience-dependent changes (Lendvai et al., 2000; Majewska and Sur, 2003). Dendrites and spines in the adult cortex remain stable for long periods of time (Trachtenberg et al., 2002; Holtmaat et al., 2005), but remodeling of spines is still able to occur, as seen in the ability of small fraction of spines to turn over in long term in vivo imaging studies (Holtmaat et al., 2005, 2006). Facilitation of new learning has been linked to increased spine formation in behavioral studies. Spatial learning and associative learning have been reported to result increased hippocampal dendritic spines (Moser et al., 1994; Leuner et al., 2003). Another example of experience-dependent remodeling that can alter hippocampal spine and synapse formation is stress exposure (Shors et al., 2001; Pawlak et al., 2005; Donohue et al., 2006). Moreover, increasing evidence links alterations in synaptic plasticity to pathological conditions. Dendritic spine and dendritic branch loss are seen in psychiatric disease in the human brain, and are linked to impairments in cognition and emotional behaviors (Lin and Koleske, 2010).
The Nogo receptor (NgR) family and their ligands have been implicated in regulating forms of experience- dependent plasticity in the adult brain (Akbik et al., 2012). NgRs are a family of neuronally expressed glycophosphatidylinositol (GPI)-anchored leucine-rich repeat proteins, initially identified through their binding to a range of myelin-associated ligands inhibitory to neurite outgrowth in the CNS (Fournier et al., 2001; Domeniconi et al., 2002; Liu et al., 2002; Venkatesh et al., 2005). Nogo receptor $1(\mathrm{NgR} 1)$ has been shown to regulate structural plasticity in the adult system. Knockout of NgR1 extends the critical period for experience-dependent plasticity in the ocular dominance paradigm in visual cortex (McGee et al., 2005), as well as extending critical period plasticity for acoustic preference (Yang et al., 2012). In addition, various forms of neuronal activity induction have been demonstrated to rapidly downregulate NgR1 expression in mice, as seen with wheel running (Josephson et al., 2003), kainic acid (Josephson et al., 2003; Mingorance et al., 2004; Wills et al., 2012; Karlsson et al., 2013), electroconvulsive seizures (Nordgren et al., 2013) and amphetamine (Guo et al., 2013). Regulation of the Nogo receptor homologs NgR2 and NgR3 by neuronal activity have also been reported (Wills et al., 2012; Karlsson et al., 2013). In support of this role in activity-dependent plasticity, $\mathrm{NgR} 1$ has been demonstrated to regulate synaptic plasticity. Ablation or blocking of NgR1 enhances hippocampal longterm potentiation (LTP) in slice preparations (Lee et al., 2008; Delekate et al., 2011), and appears to be mediated by the binding 
of NgR1 to selected ligands such as Nogo-A (Raiker et al., 2010), and fibroblast growth factor-2 (FGF2) (Lee et al., 2008). The extension of the critical period plasticity into adulthood is also reflected in an increase in spine turnover in the cortex of adult NgR1 ${ }^{-/-}$mice (Akbik et al., 2013), and a shift toward immature spine subtypes in the hippocampus of $\mathrm{NgR}^{-/-}$mice (Lee et al., 2008; Zagrebelsky et al., 2010). At a behavioral level, modulation of NgR1 has resulted in mild memory phenotypes. Forebrain NgR1 overexpression impairs long-term memory, without affecting short-term memory (Karlen et al., 2009), whilst constitutive knockout of NgR1 impairs working memory without affecting spatial memory (Budel et al., 2008). Additionally, NgR1 ${ }^{-/-}$ mice also exhibit improved extinction learning in cued conditioned fear (Akbik et al., 2013). This suggests that NgR1-mediated structural plasticity may underlie some forms of behavioral plasticity, but highlight the potential functional redundancy of these receptors.

Thus far it is not known if the Nogo receptor homolog NgR2 can also function to restrict adult plasticity. NgR2 mRNA is highly expressed in hippocampal principal neurons of CA1, CA2, CA3 and dentate gyrus (Laurén et al., 2003; Barrette et al., 2007; Funahashi et al., 2008; Karlsson et al., 2013). NgR2 expression is also detected in neurons of all layers of the cortex (Laurén et al., 2003; Barrette et al., 2007; Funahashi et al., 2008; Karlsson et al., 2013) and of the amygdaloid complex (Barrette et al., 2007; Karlsson et al., 2013). It has been demonstrated that NgR1-3 can individually restrict excitatory synapse formation in vitro, and that loss of all 3 receptors increases dendritic length and excitatory synapse formation at postnatal day (P)18 (Wills et al., 2012). Here we investigated the individual function of NgR2 using an NgR2 mutant mouse line. We examined hippocampal morphology in the adult and report that ablation of NgR2 leads to regional specific increases in mushroom-type spines whilst leaving dendritic morphology normal. Additionally, $\mathrm{NgR} 2^{-/-}$mice exhibit alterations in fear and anxiety-like behaviors. We propose that $\mathrm{NgR} 2$ has a role in maintaining spine morphology in the adult system, which may be coincident with behavioral plasticity.

\section{MATERIALS AND METHODS ETHICS STATEMENT}

All animal experiments performed were approved by the local Ethical Committee on Animal Care and Use (Bundesministerium für Wissenschaft und Kultur, Austria; approval ID: BMWF66.008/0016-II/3b/2011; BMWF-66.011/0166-II/3b/2012), in compliance with international laws and regulations for animal experimentation to minimize suffering and reduce the number of animals required.

\section{ANIMALS}

NgR2 null mutant mice were generated as described previously (Wörter et al., 2009), and backcrossed onto a C57BL/6J background for at least seven generations. All experiments were carried out on adult male littermate mice generated from NgR2 heterozygous breeding. Animals were group housed with littermates in cages under standard laboratory conditions $(12 \mathrm{~h}$ light/dark cycle with lights on at $7 \mathrm{am}, 22 \pm 1{ }^{\circ} \mathrm{C}, 60 \%$ humidity) with access to food and water ad libitum. All animals were genotyped by PCR of tail tissue.

\section{MORPHOLOGICAL ANALYSIS \\ Niss/ staining and immunohistochemistry}

Naïve adult $\mathrm{NgR} 2^{+/+}$and $\mathrm{NgR} 2^{-/-}$littermate mice $(n=4$ per genotype) were deeply anesthetized with an overdose of sodium pentobarbital and transcardially perfused with $0.9 \%$ saline followed by $4 \%$ paraformaldehyde in phosphate-buffered saline. Free-floating $40 \mu \mathrm{m}$ sections were prepared on a cryotome (Leica) and either fixed on slides and processed for cresyl violet staining, or processed for immunohistochemistry with primary antibody for NeuN (anti-mouse NeuN, Chemicon), followed by biotinylated secondary antibody, amplification with Vectastain $\mathrm{ABC}$ reagent (Vector Laboratories) and development with 3,3'diaminobenzidine chromagen. For neuron number analysis, 1 in 6 sections between Bregma -1.34 and $-2.46 \mathrm{~mm}$ were analyzed for NeuN. Images from the dorsal hippocampus were obtained using an Olympus BX51 microscope and a $20 \times$ objective. A square region of $40,000 \mu \mathrm{m}^{2}$ was placed over the CA1 pyramidal layer on the image and number of NeuN positive cells in the pyramidal layer counted, according to methods previously reported (Luikart et al., 2005). Data from 3 sections per brain were averaged together.

\section{Golgi-cox staining and analysis}

Naïve adult $\mathrm{NgR} 2^{+/+}$and $\mathrm{NgR} 2^{-/-}$littermate controls $(n=7$ per genotype) were used for morphological analysis of CA1 pyramidal cells, using the Golgi-Cox method as previously described (Champagne et al., 2008). Briefly, freshly dissected brains were immersed in Golgi-Cox fixative solution for 28 days in the dark. Samples were then dehydrated and embedded in celloidin. Coronal sections $120 \mu \mathrm{m}$ thick were cut on a sliding microtome. For staining, all sections were incubated in $16 \%$ ammonia solution to develop the impregnation, fixed in $1 \%$ sodium thiosulfate, dehydrated in ethanol, cleared in butanol and histoclear and mounted on slides.

Measurements of dendritic morphology were performed on 811 pyramidal cells per animal randomly chosen from the CA1 region of the dorsal hippocampus, defined as Bregma -0.94 to $-2.80 \mathrm{~mm}$ (Franklin and Paxinos, 2008), by an observer blinded to genotype. Neurons were selected for tracing if they meet the following previously published criteria (Champagne et al., 2008): clearly filled, dendritic branches without breaks, and without precipitate. Neurons were traced using the Neurolucida program (MBF Biosciences, v10) attached to an Olympus BX51 microscope, using a $40 \times$ objective. Sholl and branching analysis of traced neurons was performed with Neurolucida Explorer program (MBF Biosciences).

For dendritic spine analysis, tertiary dendrites from the same CA1 pyramidal neurons were imaged with a $100 \times$ oil objective. Segments approximately $20 \mu \mathrm{m}$ long were analyzed from each branch, by an observer blinded to genotype. Two to six tertiary segments per neuron were analyzed. Segments were analyzed from two regions of CA1 stratum radiatum (SR): 30 $120 \mu \mathrm{m}$ from the soma, and $120-300 \mu \mathrm{m}$ from the soma. A spine had to be continuous to the dendritic shaft in order to 
be counted. The Neurolucida program (MBF Biosciences, v10) was used to assign spine categories to each spine, using previously described criteria for thin, stubby or mushroom spines. Density was determined by dividing number of spines on a segment by the length of that segment. Mean spine densities were obtained by averaging values per neuron, a widely accepted method of analysis in Golgi studies of dendritic morphology (Vyas et al., 2002; Chakravarthy et al., 2006; Pillai et al., 2012).

\section{BEHAVIORAL ANALYSIS}

Adult $\mathrm{NgR} 2^{+/+}, \mathrm{NgR} 2^{+/-}$, and $\mathrm{NgR} 2^{-/-}$littermate mice were subjected to a battery of behavioral tests. For each test $n=8-16$ mice per genotype were tested.

\section{Morris water maze}

In a circular pool ( $1.2 \mathrm{~m}$ in diameter) filled with opaque water $\left(22^{\circ} \mathrm{C}\right)$ and illuminated at $70 \mathrm{lux}$, an escape platform $(10 \mathrm{~cm}$ diameter) was hidden just below the water surface. Starting from variable positions, mice were placed into the water from which they could escape by climbing onto the platform. In case the animal was not able to locate the platform within $60 \mathrm{~s}$, it was gently guided to it by the experimenter. The animals were allowed to stay on the platform for $30 \mathrm{~s}$. On each of two consecutive training days, animals performed four trials separated by $60 \mathrm{~min}$ prior to probe trials 1 and 2 and probe trial reversal learning. The platform always remained in the same quadrant for each training session, but in the opposite quadrant for reversal learning while it was removed for the probe trials. In probe trials animals were allowed to swim in the pool for $60 \mathrm{~s}$ and the time the mice spent in the target quadrant was recorded.

\section{Contextual fear conditioning}

Contextual fear conditioning was performed as previously described (Sartori et al., 2011), in a fully automated fearconditioning system (TSE, Technical \& Scientific Equipment GmbH, Bad Homburg, Germany) consisting of a Perspex arena $(23 \times 23 \times 35 \mathrm{~cm})$ and a metal grid floor. For conditioning, mice were placed into the brightly illuminated (300 lux) context and 3 unsignaled mild foot shocks $(0.6 \mathrm{~mA}, 2 \mathrm{~s}$; US) were delivered. Two-minutes stimulus-free periods preceded, separated and followed the US presentations. Twenty-four hours after fear conditioning, mice were returned to the same context for $3 \mathrm{~min}$ to assess fear expression. The arena was thoroughly cleaned with tap water between each animal. All sessions were recorded via individual video cameras mounted above each context. Freezing behavior, defined as the absence of all non-respiratory movements (Blanchard and Blanchard, 1969; Fanselow, 1980), was taken as the measure of fear and was scored by an experienced investigator blinded to mouse lines and treatments. Percentages of freezing time for each mouse were calculated during each 2min period post US presentation in the conditioning and during the 3-min context exposure in the fear expression tests. Six out of 42 mice in different experimental groups were insufficiently conditioned as they showed less than $10 \%$ freezing behavior after the final US presentation, and were therefore removed from the data set.

\section{Flinch/jump test}

The flinch/jump test was performed according to a previous protocol (Sartori et al., 2011). Animals were individually placed in the conditioning chambers (see above). After 2 min of habituation to the chamber, animals were subjected to $1 \mathrm{~s}$ shocks of gradually increasing amperage $(0.1 \mathrm{~mA}$ every $30 \mathrm{~s})$ starting at $0.1 \mathrm{~mA}$. Mice were scored for their first visible response to the shock (flinch), their first pronounced motor response (run or jump), and for their first vocalized distress.

\section{Open field}

The open field consisted of a plastic box $(41 \times 41 \times 41 \mathrm{~cm})$ equipped with an automated activity monitoring system (TruScan, Coulbourn Instruments, USA). The area of the open field, illuminated with 150 lux, was divided into a $28 \times$ $28 \mathrm{~cm}$ central zone and a surrounding border zone. Mice were placed individually into the periphery of the open field and allowed to explore it for $10 \mathrm{~min}$. The following anxiety-related parameters were recorded: entries into the central zone, time spent in it and the overall distance traveled (Sartori et al., 2011).

\section{Tail suspension test}

The tail suspension test was performed as previously described (Schmuckermair et al., 2013). Mice were fastened with medical adhesive tape by the tip of the tail to a flat metallic surface and suspended for $6 \mathrm{~min}$ approximately $30 \mathrm{~cm}$ above the floor surface. Illumination was set at 100 lux. The activity of the mice was videotaped, and immobility, defined as when the animal hung passively without limb movement, was scored over the entire 6 min test session by a trained observer blinded to genotype. Data from the last $4 \mathrm{~min}$ of the test was analyzed.

\section{Rotarod}

The apparatus consisted of a rotating rod (diameter $3 \mathrm{~cm}$ ) covered with a ribbed black rubbery surface (TSE, Bad Homburg, Germany). Mice received three training sessions (within $45 \mathrm{~min}$ ) to remain on the rotating rod while it was accelerated from 4 to $40 \mathrm{rpm}$ within $600 \mathrm{~s}$ (Paylor et al., 2006). The latency to fall off the rotating drum was recorded.

\section{HORMONE ANALYSIS}

For corticosterone and adrenocorticotrophic hormone (ACTH) measurements, naïve $\mathrm{NgR} 2^{+/+}, \mathrm{NgR} 2^{+/-}$, and $\mathrm{NgR} 2^{-/-}$animals were decapitated between 8:00 and 12:00 am. Trunk blood samples were immediately collected and centrifuged at high speed to separate the plasma and stored at $-20^{\circ} \mathrm{C}$ until the assay was carried out. Plasma corticosterone and ACTH concentrations were measured with radioimmunoassay kits (MP Biomedicals) according to the manufacturer's instructions. The manufacturer-reported intra-assay and inter-assay coefficient of variation were $\leq 10 \%$ for all kits used. Two separate cohorts of animals were used and corticosterone and ACTH values were normalized to $\mathrm{NgR} 2^{+/+}$in both cohorts before being pooled for analysis. This resulted in a total $n$ of $8-9$ animals/genotype for ACTH measurements and 9 animals/genotype for corticosterone measurements. 


\section{STATISTICS}

Statistical analysis was conducted using SPSS or Statistica. Morphological data and hormone data were analyzed using student's $t$-test to compare genotypes. Behavioral studies were analyzed using student's $t$-test, One-Way ANOVA, or Two-Way repeated measures ANOVA, unless noted otherwise. Post-hoc comparisons were performed using Fisher's protected least significant difference (Fisher's PLSD) multiple comparisons. Statistical significance was set at $p<0.05$. Values in graphs are expressed as mean \pm s.e.m.

\section{RESULTS \\ LOSS OF NgR2 ALTERS DISTRIBUTION OF SPINE MORPHOLOGIES IN THE HIPPOCAMPUS}

In order to study the effects of NgR2 on adult neuronal plasticity, we used adult ( $8-10$ week) $\mathrm{NgR} 2^{-/-}$and $\mathrm{NgR} 2^{+/+}$ littermate controlled mice, generation of which has been previously detailed (Wörter et al., 2009). Anatomy of Nissl-stained $\mathrm{NgR} 2^{-/-}$brains appeared normal compared to littermate controls (Figure 1A). Neuronal density in the hippocampus was analyzed using immunohistochemistry for the neuron-specific marker NeuN. No significant change in the density of NeuNpositive cells was observed in the hippocampal CA1 region (mean NeuN positive cells counted in $40,000 \mu \mathrm{m}^{2}$ area of CA1: $\mathrm{NgR} 2^{+/+}=72.8 \pm 1.7$ cells, NgR2 ${ }^{-/-}=71.6 \pm 1.0$ cells; $t=$ $0.62, p=0.56)$. Constitutive knockout of all three NgRs increases hippocampal dendritic complexity in vivo at P18 during development (Wills et al., 2012), but it is not known if loss of $\mathrm{NgR} 2$ function alone can influence dendritic geometry and spine density in adult neurons. We used Golgi-Cox staining to visualize individual CA1 pyramidal neurons in adult mice (Figure 1B), and analyzed their dendritic trees. Sholl analysis of reconstructed CA1 neurons from $\mathrm{NgR} 2^{+/+}$and $\mathrm{NgR} 2^{-/-}$mice showed no genotype differences in complexity of basal and apical dendritic trees, as measured by the number of intersections over distance (Figures 1C,E) and the number of branching points per dendrite (Figures 1D,F, Table 1). There was also no effect of genotype on the total dendritic length or the number of dendritic endings in basal and apical dendrites (Table 1). Thus, these observations indicate little, if any, change in overall dendritic structure in $\mathrm{NgR} 2^{-/-}$mice.

However, a more detailed analysis revealed striking differences in the distribution of spine sub-types on apical dendrites of CA1 pyramidal neurons. Spines from 2 to 6 tertiary dendritic segments per neuron were analyzed to obtain the averaged spine density for 54-60 CA1 pyramidal neurons per genotype (Figure 2A). Quantitative measures show a significant increase in the density of mushroom-type dendritic spines in $\mathrm{NgR} 2^{-/-}$compared to $\mathrm{NgR} 2^{+/+}$(mushroom spines $\mathrm{NgR} 2^{+/+}=0.13 \pm 0.01$ spines/ $\mu \mathrm{m}, \mathrm{NgR} 2^{-/}=0.16 \pm 0.01$ spines/ $\mu \mathrm{m} ; t=-2.288$, $p=0.02$ ), whereas thin and stubby type spines displayed similar densities between genotypes (Figure 2B). This increase did not, however lead to changes in total spine density between $\mathrm{NgR} 2^{+/+}$ and $\mathrm{NgR} 2^{-/-}\left(\mathrm{NgR} 2^{+/+}=0.60 \pm 0.02\right.$ spines $/ \mu \mathrm{m}, \mathrm{NgR} 2^{-/-}=$ $0.63 \pm 0.02$ spines/ $\mu \mathrm{m} ; t=-0.951, p=0.34$; Figures $2 \mathrm{~A}, \mathbf{B}$ ).

In the intact hippocampus, CA1 pyramidal neurons receive spatially segregated direct and indirect excitatory inputs from different anatomical sources (Spruston and McBain, 2007; Kajiwara
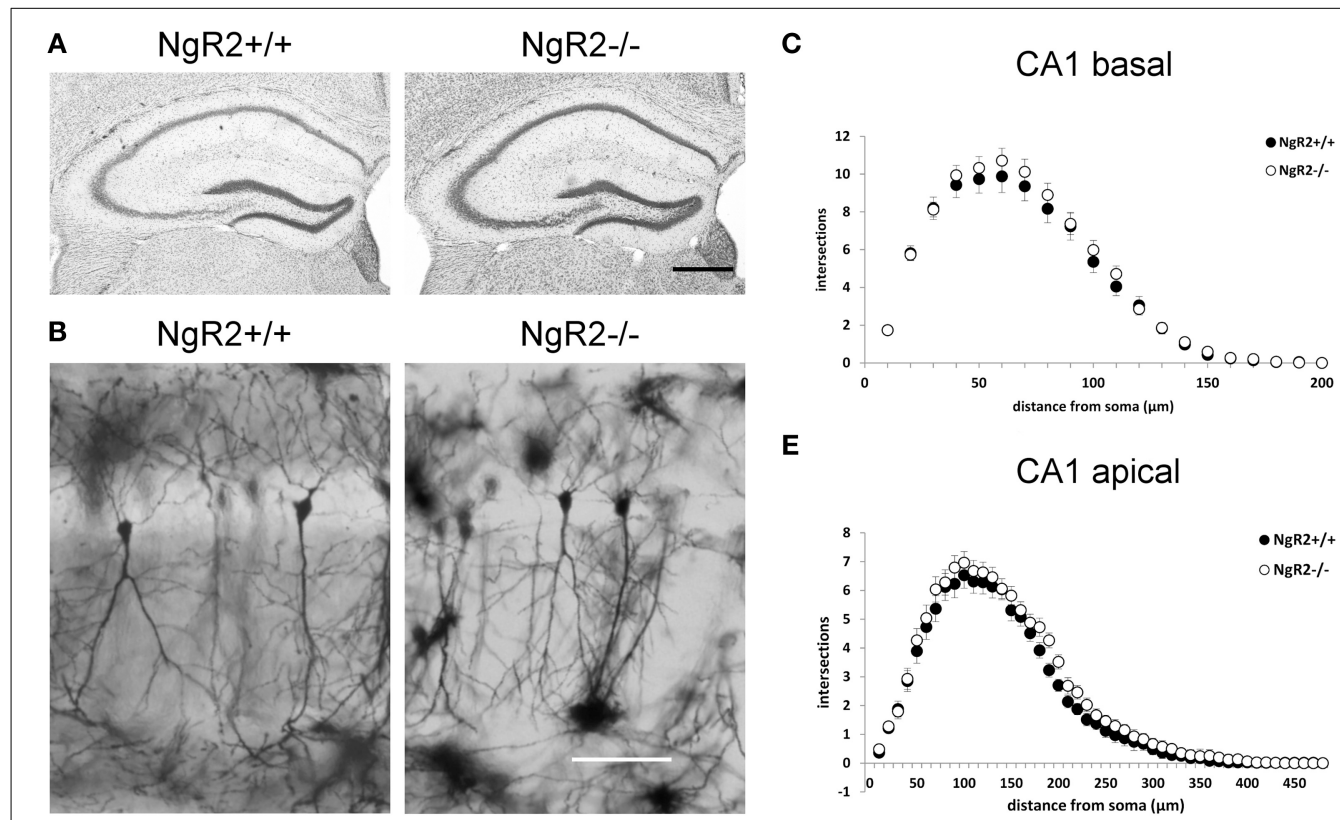

$\mathbf{E}$
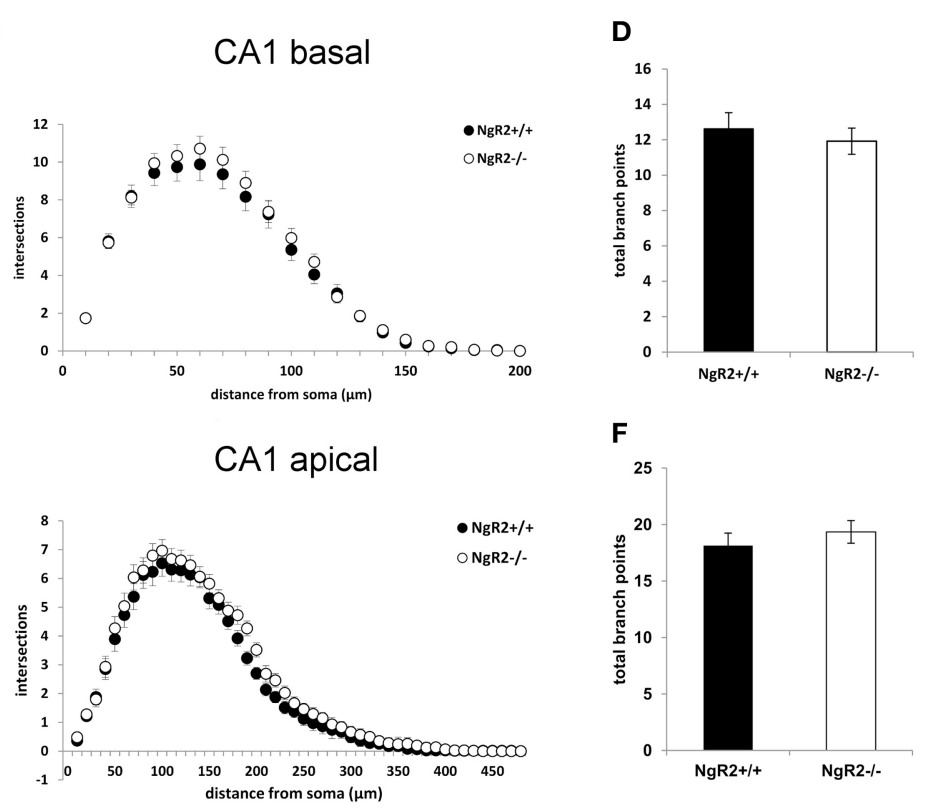

FIGURE 1 | Dendritic morphology of CA1 hippocampal neurons is similar between $\mathrm{NgR2}^{+/+}$and $\mathrm{NgR2}^{-/-}$mice. (A) Nissl staining of coronal sections from $\mathrm{NgR}^{+/+}$and $\mathrm{NgR2} 2^{-/-}$hippocampus. (B) Representative images of Golgi-Cox stained pyramidal cells in hippocampal CA1 region in $\mathrm{NgR}^{+/+}$and NgR2 ${ }^{-/-}$. (C,D) Sholl analysis of dendritic complexity in CA1 basal dendrites. Number of intersections were similar between genotypes (D). (E,F) Sholl analysis of dendritic complexity in CA1 apical dendrites. Number of intersections (E) and total branch points (F) were unaltered between genotypes. Scale bars: (A) $200 \mu \mathrm{m}$, (B) $100 \mu \mathrm{m}$. (C), and the total number branch points were unaltered between genotypes 
Table 1 | Morphological analysis of apical and basal dendrites in CA1 hippocampal cells from $\mathrm{NgR2}^{+/+}$and $\mathrm{NgR2}^{-/-}$animals.

\begin{tabular}{|c|c|c|c|c|c|c|}
\hline \multirow[t]{2}{*}{ Genotype } & \multicolumn{3}{|c|}{ Apical } & \multicolumn{3}{|c|}{ Basal } \\
\hline & $\mathrm{NgR2}^{+/+}$ & $\mathrm{NgR2}^{-/-}$ & $p$-value & $\mathrm{NgR2}^{+/+}$ & $\mathrm{NgR2}^{-/-}$ & $p$-value \\
\hline Total no of intersections & $102.1 \pm 5.5$ & $114.1 \pm 5.5$ & 0.1 & $85.7 \pm 5.9$ & $80.6 \pm 5.1$ & 0.5 \\
\hline Total dendritic length $(\mu \mathrm{m})$ & $1541 \pm 89$ & $1675 \pm 84$ & 0.3 & $1124 \pm 79$ & $1132 \pm 67$ & 0.9 \\
\hline Total no of branch points & $18.1 \pm 1.1$ & $19.3 \pm 1.0$ & 0.4 & $12.6 \pm 0.9$ & $11.9 \pm 0.7$ & 0.6 \\
\hline Total no of branch tips & $19.4 \pm 1.1$ & $20.9 \pm 1.0$ & 0.4 & $16.7 \pm 1.0$ & $16.3 \pm 0.8$ & 0.7 \\
\hline
\end{tabular}

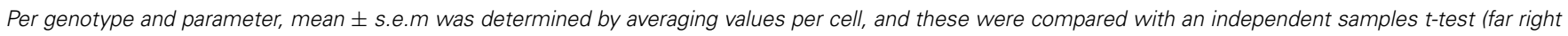
column). $N=7$ animals/genotype, $n=74-83$ cells/genotype apical, $n=42-49$ cells/genotype basal.

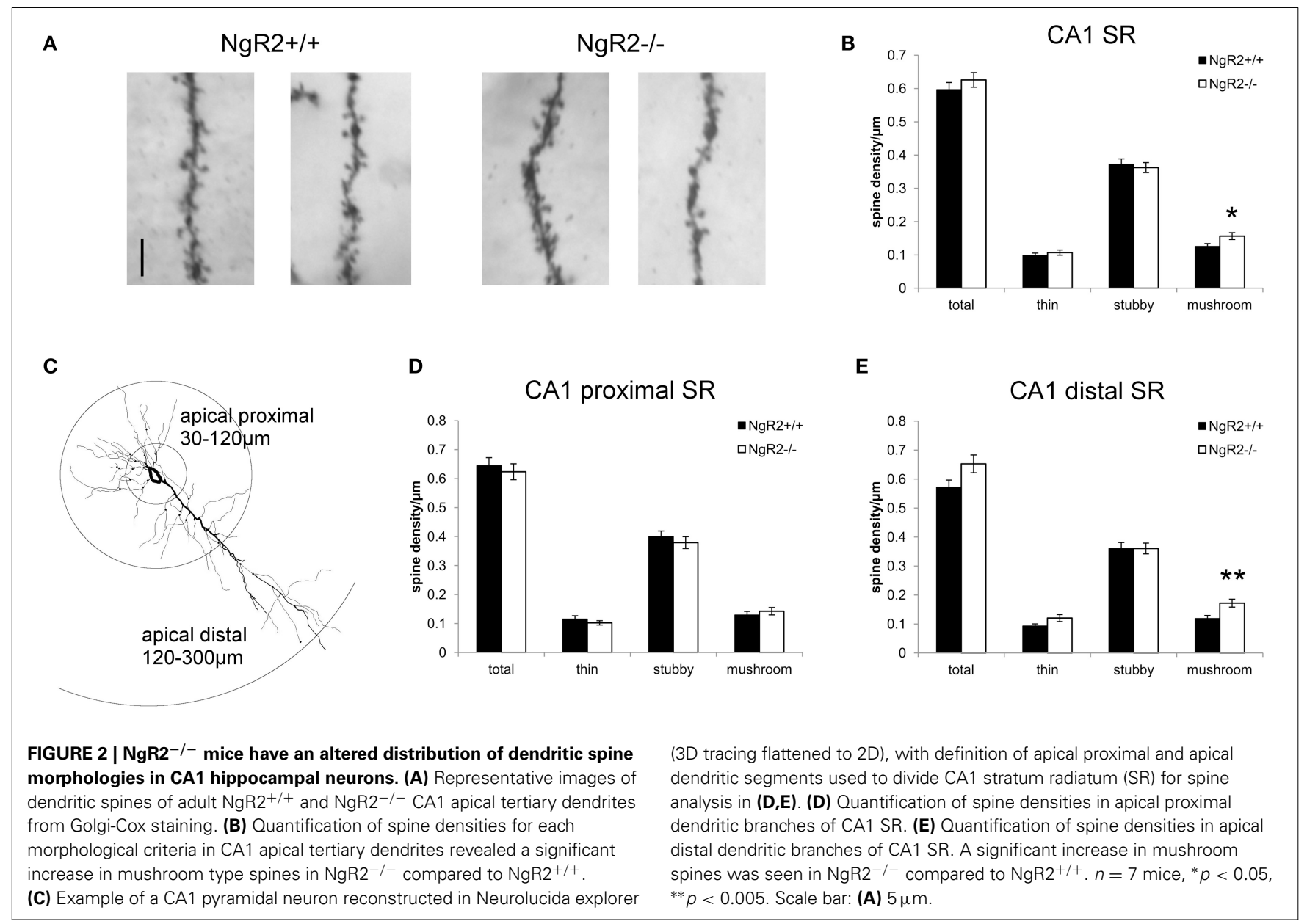

et al., 2008). Schaffer collateral input from CA3 terminates on CA1 dendrites in both SR (apical dendrites) and stratum oriens (basal dendrites). The majority of input to CA1 apical dendrites is to the distal two-thirds of SR (Bannister and Larkman, 1995), and fewer synapses are made onto dendritic segments in the proximal SR region (Megías et al., 2001). Therefore, to measure spine density in the region of CA1 apical dendrites receiving the majority of Schaffer collateral input, we reanalyzed the spine data to take account of distance of dendritic segment from the soma. Spine morphology and spine density analysis were confined to the tertiary dendritic segments of the CA1 proximal SR (30-120 $\mu \mathrm{m}$ from the cell soma), and distal
SR at distances $120-300 \mu \mathrm{m}$ from the cell soma (Figure 2C), similar to previously published classifications (Perez-Cruz et al., 2011; Pillai et al., 2012). No genotype alterations in total spine density nor in the proportion of morphological sub-types were seen within the proximal CA1 SR subfield (total $t=0.27, p=$ 0.60 ; thin $t=1.0, p=0.32$; stubby $t=0.13$, $p=0.48$; mushroom $t=0.30, p=0.48$; Figure $2 \mathrm{D})$. In contrast, a significant increase in mushroom type spines in $\mathrm{NgR} 2^{-/-}$was quantified in the distal SR, where proportion of mushroom spines increased by $41.6 \%$ compared to $\mathrm{NgR} 2^{+/+}\left(\mathrm{NgR} 2^{+/+}=0.12 \pm\right.$ 0.01 spines $/ \mu \mathrm{m}, \mathrm{NgR} 2^{-/-} 0.17 \pm 0.01$ spines $/ \mu \mathrm{m} ; t=0.61, p=$ 0.004 , Figure 2E). Interestingly, this increase in mushroom 
spines in distal SR was not accompanied by an alteration in stubby spines (stubby $t=0.94 p=1.0$ ), and whilst a trend toward increased thin spines was observed, it was not statistically significant (thin $t=0.001 p=0.056$ ). This was reflected in the slight but non-significant increase in total dendritic spine density in $\mathrm{NgR} 2$ knockout mice $\left(\mathrm{NgR} 2{ }^{+/+} 0.57 \pm\right.$ 0.02 spines $/ \mu \mathrm{m}, \mathrm{NgR} 2^{-/-} 0.65 \pm 0.03$ spines $/ \mu \mathrm{m} ; t=0.088 p=$ 0.053; Figure 2E). Moreover, the increase was not attributable to changes in dendritic diameter of tertiary segments analyzed $\left(\mathrm{NgR} 2^{+/+}=0.47 \pm 0.03 \mu \mathrm{m}, \mathrm{NgR} 2^{-/-}=0.43 \pm 0.01 \mu \mathrm{m}, t=\right.$ $1.09 p=0.29)$. We thus conclude that $\mathrm{NgR} 2$ has a role in regulating maintenance of mature spines in adult hippocampal neurons.

\section{NgR2-/- MICE HAVE REDUCED FEAR EXPRESSION AND ANXIETY-LIKE BEHAVIOR}

Changes in spine density in CA1 have been reported to be correlated with stress exposure (Shors et al., 2001; Pawlak et al., 2005; Donohue et al., 2006), learning and memory (Moser et al., 1994, 1997), and anti-depressant effects (Wang et al., 2013) in rodents. Moreover, given that activity-regulated genes are implied to contribute to plasticity (Leslie and Nedivi, 2011), and the recent suggestions that $\mathrm{NgRs}$ are regulated by various forms of activity stimuli (Guo et al., 2013; Karlsson et al., 2013), we next examined whether the alterations in spine distribution seen in $\mathrm{NgR} 2^{-/-}$ mice may also affect behavioral tasks in the adult, such as learning and memory.

To test spatial learning and memory, mice were tested in the hidden platform test of the Morris water maze. NgR2 ${ }^{-/-}$ mice showed no alterations in learning of the spatial navigation task, as measured by the time spent in the correct quadrant of the pool [genotype effect: $F_{(2,32)}=0.19, p=0.83$; genotype $\times$ trial: $F_{(2,32)}=0.02, p=0.98$; Figure $\left.3 \mathrm{~A}\right]$. In a reversal learning trial there were also no genotype differences in ability to learn a new hidden platform location $\left[F_{(2,33)}=0.57\right.$, $p=0.57$; Figure 3A]. No deficits in swimming ability were seen (data not shown). To further explore differences in memory between $\mathrm{NgR} 2^{+/+}$and $\mathrm{NgR} 2^{-/-}$animals, a separate cohort of mice were tested for contextual fear conditioning, a form of classical conditioning that is hippocampal dependent (Phillips and Ledoux, 1992; Anagnostaras et al., 2001). Fear acquisition as indicated by increases in freezing behavior in response to repeated context-shock exposures was normal in $\mathrm{NgR} 2^{-/-}$compared to $\mathrm{NgR} 2^{+/+}$and $\mathrm{NgR} 2^{+/-}$[genotype effect: $F_{(2,35)}=$ $1.27 ; p=0.29$; Figure 3B]. Since the three groups of mice displayed comparable increases in freezing [conditioning effect: $F_{(3,105)}=104.94, p<0.001$; conditioning $\times$ genotype interaction: $\left.F_{(6,1105)}=0.53, p=0.78\right]$, it is suggested that there was no sensorimotor performance deficit, such as an inability to freeze. This is also supported by results from the flinchjump test in another separate cohort of mice, which showed no differences between $\mathrm{NgR} 2^{-/-}$and $\mathrm{NgR} 2^{+/+}$in their threshold to flinch $\left(\mathrm{NgR} 2^{+/+}=0.10 \pm 0.0 \mathrm{~mA}, \mathrm{NgR} 2^{-/-}=0.13 \pm\right.$ $0.03 \mathrm{~mA}, t=0.36, p=0.36)$, to jump $\left(\mathrm{NgR} 2^{+/+}=0.23 \pm\right.$ $\left.0.06 \mathrm{~mA}, \mathrm{NgR} 2^{-/-}=0.18 \pm 0.08 \mathrm{~mA}, t=0.51, p=0.62\right)$ or to vocalize $\left(\mathrm{NgR} 2^{+/+}=0.13 \pm 0.03 \mathrm{~mA}, \mathrm{NgR}^{-/-}=0.25 \pm\right.$ $0.08 \mathrm{~mA}, t=1.81, p=0.12$ ). Fear expression $24 \mathrm{~h}$ later differed between genotypes $\left[F_{(2,35)}=4.48, p=0.02\right]$ as it was significantly reduced in $\mathrm{NgR} 2^{-/-}$compared to $\mathrm{NgR} 2^{+/+}(p=$ $0.03)$ and $\mathrm{NgR} 2^{+/-}(p=0.006$; Figure 3B $)$. Reduced freezing could indicate either impairments in memory or impairments in fear response. As we do not detect differences in other tests of spatial and associative memory, this suggests that the reduced freezing seen in contextual fear conditioning may well be due to an altered fear response.

As alterations in anxiety have been shown to be coincident with changes in fear expression (Sartori et al., 2011), we also assessed anxiety-like behaviors in $\mathrm{NgR} 2^{-/-}$mice. In the open field test, $\mathrm{NgR} 2^{-/-}$showed a significant increase in exploratory behavior compared to $\mathrm{NgR} 2^{+/+}$and $\mathrm{NgR} 2^{+/-}$, as measured by the number of entries $\left[F_{(2,33)}=6.03, p=0.01\right.$, Figure $\left.3 \mathrm{C}\right]$ and time $\left[F_{(2,33)}=4.18, p=0.02\right.$, Figure 3D] spent in the aversive center area, which is usually thought to reflect reduced anxiety (Miyakawa et al., 2001). Locomotor activity in the open field was similar across genotypes, as measured by the total distance traveled $\left[F_{(2,33)}=1.97, p=0.16\right.$; Figure $\left.3 E\right]$. In the tail suspension test, NgR2 ${ }^{-/-}$exhibited less immobility compared to littermate controls $\left[F_{(2,23)}=6.15, p=0.007\right.$, Figure $\left.3 F\right]$, indicative of a decrease in depression-like behavior. This finding fits in the context of the high co-morbidity between clinical disorders of anxiety and depression, which is also reflected in the overlap between tests used to model symptoms of these disorders in rodents (Cryan and Holmes, 2005). In addition to measuring activity in the open field, motor abilities of mice were also tested on the rotarod. No significant alterations in the performance in the rotarod task between genotypes were observed [genotype effect: $F_{(2,31)}=2.95, p=0.07$; trial $\times$ genotype interaction: $F_{(4,62)}=$ $1.22, p=0.31$; Figure 3G], thus it seems unlikely that alterations in the open field exploration and tail suspension test in $\mathrm{NgR} 2^{-/-}$ mice were due to abnormalities in locomotor activity.

The phenotype of increased anxiolytic and reduced fear behavior led us to wonder if $\mathrm{NgR} 2^{-/-}$mice were more resilient to stress, leading to better performance under the stressful circumstances of behavioral testing. Basal levels of stress hormones have been reported to correlate with performance in tests of anxiety-like and depression-like behavior in mouse models of stress reactivity (Wittmann et al., 2009; Chourbaji et al., 2010). Therefore, the basal concentrations of ACTH and corticosterone were measured in naïve $\mathrm{NgR} 2^{+/+}$and $\mathrm{NgR} 2^{-/-}$mice. $\mathrm{NgR} 2^{-/-}$ mice seemed to have reduced basal ACTH $\left(\mathrm{NgR} 2^{+/+}=100.0 \pm\right.$ $\left.38 \%, \mathrm{NgR}^{-/-}=37.8 \pm 9.4 \%\right)$ and corticosterone $\left(\mathrm{NgR} 2^{+/+}=\right.$ $\left.100.0 \pm 33 \%, \mathrm{NgR}^{-/-}=52.7 \pm 14.2 \%\right)$ concentrations compared to $\mathrm{NgR} 2^{+/+}$, but due to high variability, this did not reach statistical significance (ACTH: $t=1.66, p=0.12$; CORT: $t=$ $1.32, p=0.21$; Figure 4). These results indicate that $\mathrm{NgR} 2^{-/-}$ mice have reduced fear and anxiety-type behaviors without a significant shift of basal hypothalamic-pituitary-axis activity.

\section{DISCUSSION}

In this study we show for the first time that constitutive knockout of NgR2 can alter spine morphology in the adult hippocampus, increasing mushroom-type spines on apical dendrites of CA1 neurons, specifically in distal SR. Coincident with this, absence of NgR2 results in reduced fear, anxiety- and depression-related behaviors. We conclude that NgR2 is involved in maintenance 


\section{A}

MWM

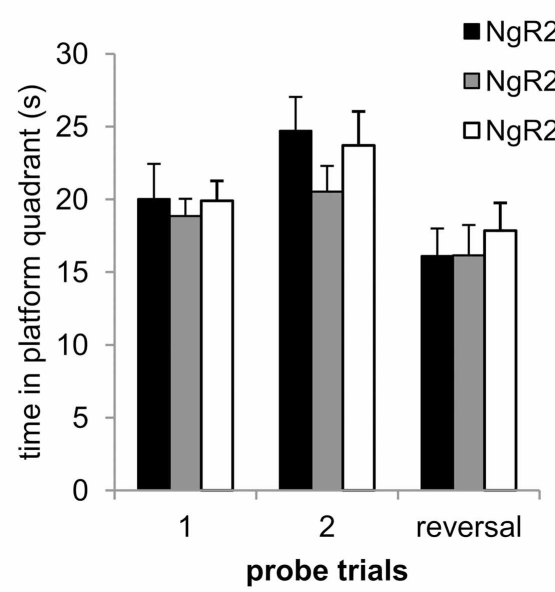

в

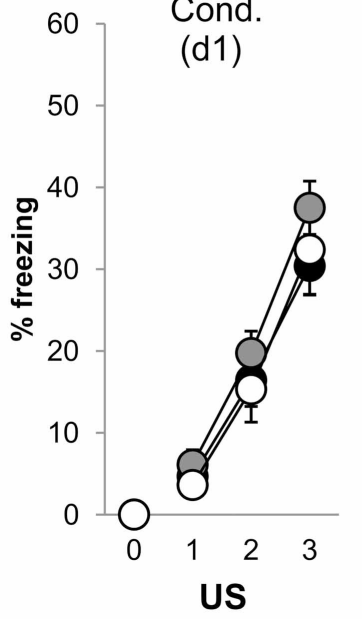

CFC

Fear expression

$(\mathrm{d} 2)$

- $\mathrm{NgR} 2+/+$

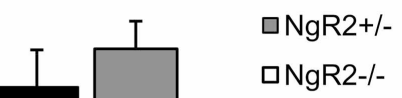

$\square \mathrm{NgR} 2-/-$

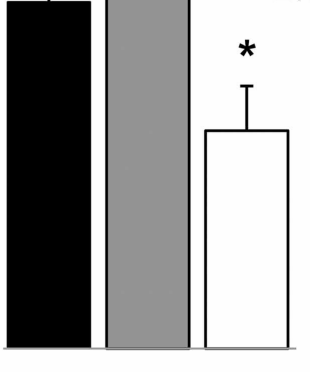

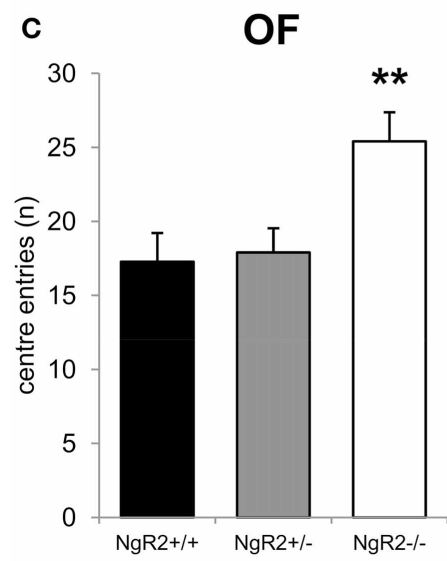
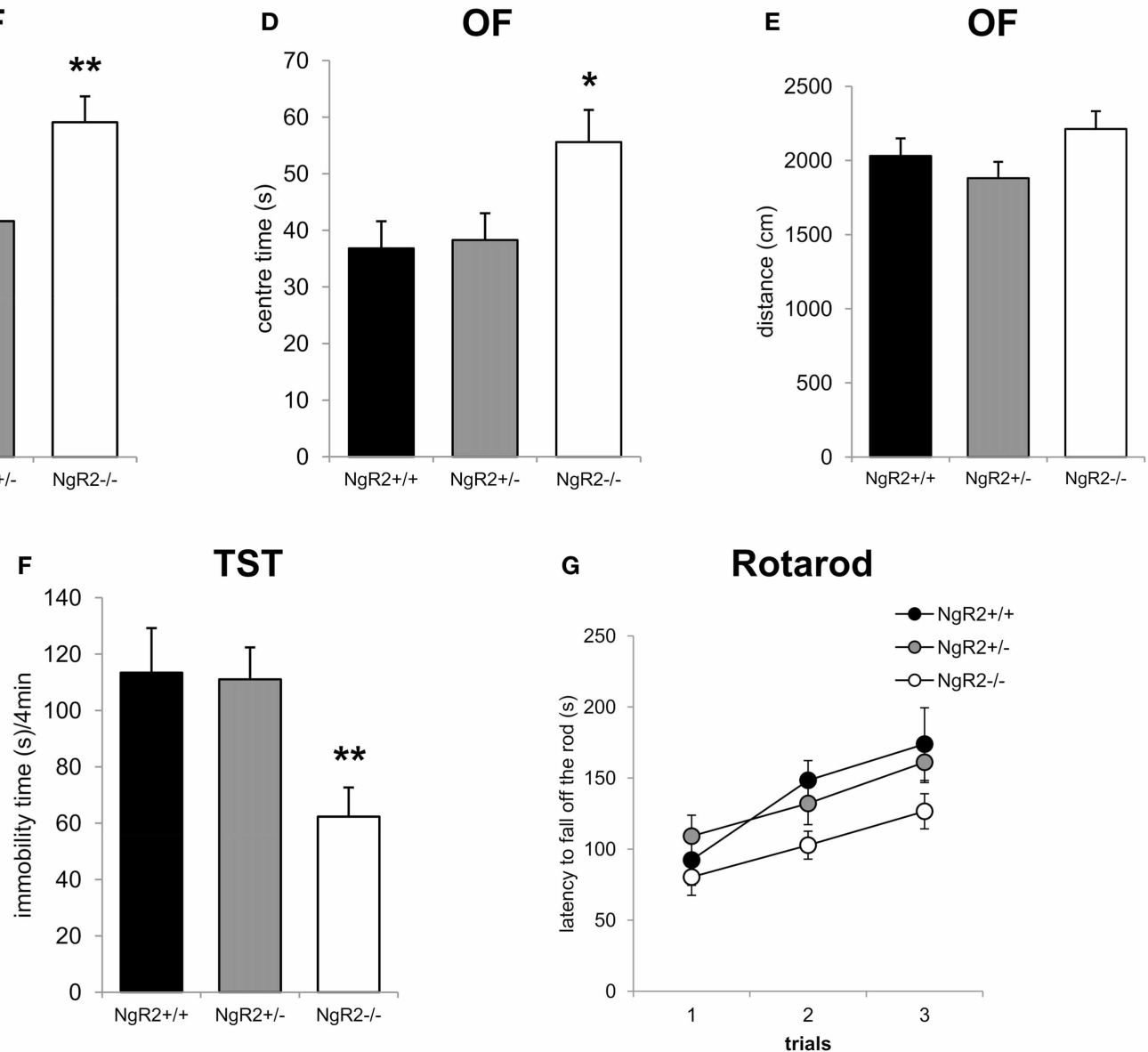

FIGURE 3 | Altered emotionality in $\mathbf{N g R 2}^{-/-}$mice. (A) In the Morris water maze $\mathrm{NgR} 2^{+/+}, \mathrm{NgR} 2^{+/-}$, and $\mathrm{NgR} 2^{-/-}$did not differ in the time spent in the platform quadrant of the maze during 2 probe trials and a reversal trial. (B) Contextual fear conditioning. $\mathrm{NgR} 2^{+/+}, \mathrm{NgR} 2^{+/-}$, and $\mathrm{NgR} 2^{-/-}$mice show similar acquisition of the task, measured by increased freezing behavior over 3 presentations of the unconditioned stimulus (US) in the context. On $\mathrm{d} 2$, exposure to the context alone elicited reduced freezing behavior in $\mathrm{NgR} 2^{-/-}$compared to $\mathrm{NgR} 2^{+/+}$and $\mathrm{NgR} 2^{+/+}$. (C-E) In the open field,

$\mathrm{NgR} 2^{-/-}$mice had more center entries (C) and spent increased time in the center (D) compared to $\mathrm{NgR} 2^{+/+}$and $\mathrm{NgR} 2^{+/-}$, without any changes in distance traveled in the arena (E). (F) $\mathrm{NgR}^{-/-}$mice exhibited decreased immobility time in the last $4 \mathrm{~min}$ of the tail suspension test. (G) In the rotarod test no genotype differences were seen in latency to fall off the rod over 3 trials. $n=8-16$ for $\mathrm{NgR} 2^{+/+}$mice, $n=8-14$ for $\mathrm{NgR} 2^{+/-}$, and $n=8-15$ for $\mathrm{NgR}^{-1-}$ mice. ${ }^{*} p<0.05$ and ${ }^{* *} p<0.01 \mathrm{NgR}^{-/-}$vs. $\mathrm{NgR} 2^{+/+}$ (analyzed by ANOVA and post Fisher's LSD test). 


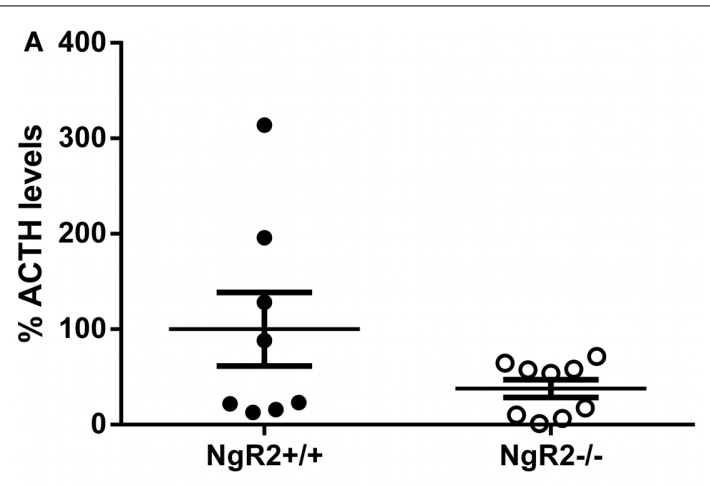

B

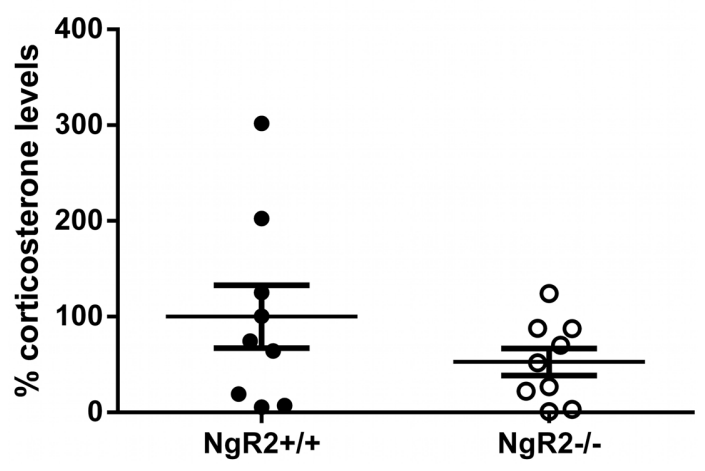

FIGURE 4 | Basal ACTH and corticosterone levels in $\mathrm{NgR2}^{-/-}$mice. (A) Basal ACTH measurements normalized to $\mathrm{NgR}^{+/+}$. (B) Basal corticosterone measurements normalized to $\mathrm{NgR} 2^{+/+} . n=8-9 / g e n o t y p e$ for ACTH, $n=9 /$ genotype for corticosterone, data pooled from 2 cohorts of animals.

of mature spines in addition to its role in restricting synapse formation.

In the adult system, a role for $\mathrm{NgR} 1$ in regulating synaptic turnover has been elucidated, but comparatively little is known about NgR2. NgR1 knockout resulted in a shift of spine morphologies in CA1 apical dendrites, with density of stubby spines increased and mushroom and thin spines decreased (Lee et al., 2008; Delekate et al., 2011), and recent work has shown that in the cortex, spine turnover in NgR1 knockout mice is significantly increased (Akbik et al., 2013). This implies regulation of spine motility by NgR1. Our findings suggest that NgR2 also has a role in regulation of the morphology of dendritic spines. We find that knockout of NgR2 increases mushroom type spines on distal apical dendrites in the adult CA1, whilst not significantly altering proportions of thin or stubby spines. Here it should be noted that relative proportions of spine subtypes reported in fixed tissue in the CA1 region vary in the literature. We report here a higher proportion of stubby spines relative to mushroom spines, which has also been observed by Beltrán-Campos and co-workers and Sanders and co-workers (Beltrán-Campos et al., 2011; Sanders et al., 2012), whereas other studies have found the reverse ratio (Rauskolb et al., 2010; Görlich et al., 2012), or comparatively equal proportions of both subtypes (Lee et al., 2008). These differences are most likely accounted for by methodological differences between studies, particularly with regards to whether spine subtype characterization was carried out with computational or observational methods, and the dendritic branch order of analyzed spines.

Mushroom-type spines have been shown to have an increased number of AMPA receptor subunits (Matsuzaki et al., 2001; Matsuo et al., 2008) and a larger post-synaptic density, which increases their spine head size and are hallmarks of excitatory, or asymmetric synapses (Sheng and Hoogenraad, 2007). Our results, combined with the findings that in vitro $\mathrm{NgR} 2^{-/}$hippocampal neurons have increased excitatory synapses (Wills et al., 2012), raises the possibility that this could correspond to an increase in excitatory synapses in adult $\mathrm{NgR} 2^{-/-}$mice, which requires further investigation. Whilst we show here that adult spine morphology is altered, it is possible that constitutive loss of NgR2 affects spine morphology already during development. In juvenile mice lacking both NgR1 and NgR2, no differences in CA1 spine density are seen (Wills et al., 2012), but changes in spine subtype distribution at this developmental stage have not been studied.

Interestingly, however, conditional deletion of $\mathrm{NgR} 1$ in aged mice increased spine turnover of cerebral cortex neurons to the same level as seen in constitutive $\mathrm{NgR} 1^{-/-}$mice in adulthood (Akbik et al., 2013), suggesting a role of NgR1 in stabilizing dendritic spines in the adult cortex. However, it remains to be seen if the effect of NgR2 on spine maturation is temporally specific to developmental or adult windows of plasticity.

Spine morphogenesis involves both spine motility and spine stabilization. The protrusive motility of filopodia and stabilization of spines by head morphing have been demonstrated to be separately regulated stages of spinogenesis (Tashiro and Yuste, 2004). Applying this model to our data on NgR2 would suggest that NgR2 might be involved in processes to inhibit the morphing of immature spine subtypes into mushroom-type spines, and therefore regulation of spine stability. This would suggest that $\mathrm{NgR} 2$ is not required for spine motility, as $\mathrm{NgR} 1$ is, although further experiments must be done to investigate this.

$\mathrm{NgR} 1$ has been shown to be located on dendrites and to be enriched pre- and post-synaptically (Wang et al., 2002b; Lee et al., 2008; Raiker et al., 2010; Wills et al., 2012). However, it is not confirmed if $\mathrm{NgR} 2$ also is present at synaptic sites. Its presence in the human post-synaptic density has been suggested by a recent study, although it was not consensus in all samples (Bayés et al., 2012). Due to the absence of a good antibody against this receptor, more precise sub-cellular localization is currently lacking, though there is suggestion of dendritic localization in hippocampal cultures, in a similar pattern to that seen with NgR1 (Wills et al., 2012). The region-specific differences we observed in spine morphology, with increased mushroom spines in distal SR but no differences in proximal SR, could be due to differential localization of NgR2 across pyramidal neurons. Another possibility is that alterations are only seen in distal SR due to input-specific regulation of synaptic function. The increase in mushroom type spines in distal SR, suggest that knockout of NgR2 might be affecting synaptic efficacy at excitatory Schaffer collateral input from CA3. Given the role already described for NgR1 in negatively regulating LTP at Schaffer collaterals (Lee et al., 2008; Delekate et al., 2011), this warrants further investigation. Limitations of the 
Golgi-Cox method mean we were not able to analyze dendritic spine density throughout the full extent of SLM, so we cannot exclude that spine differences are also observed in this region, which receives direct input from entorhinal cortex and basolateral amygdala, as well as thalamic and septal projections. Possible functional redundancy of NgRs should also be considered. The effects observed in spine density in NgR2 null mutants, as well as NgR1 null mutants (Lee et al., 2008), are small compared to that seen in NgR triple knockout mice (Wills et al., 2012). Another recent study using NgR triple knockout mice also suggests a functional redundancy effect of these receptors in regeneration after injury (Dickendesher et al., 2012).

Observations of reduced fear and anxiety alongside CA1 specific spine alterations in $\mathrm{NgR} 2^{-/}$mice is of particular note due to the involvement of the CA1 region of the hippocampus in mediating anxiety and fear behaviors. Inactivation of dorsal CA1 with the $\mathrm{GABA}_{\mathrm{A}}$ agonist muscimol increased anxiolytic response in the elevated plus maze (Rezayat et al., 2005). Lesions to dorsal CA1 or transaction of CA1 efferents to the septum indicated that dorsal CA1 was involved in both the encoding and retrieval of contextual fear (Hunsaker and Kesner, 2008; Hunsaker et al., 2009). Additionally, fear and anxiety behaviors have been shown to alter dendritic spine density in the CA1 region. An anxiolytic phenotype was seen after repeated injection with the TCAP-1, a teneurin C-terminal associated peptide, and in the same animals increases in spine density were seen in apical dendrites in CA1 SR and SLM (Tan et al., 2011). In mice selectively bred for high or low stress reactivity, spine density was increased in distal SR of low stress reactive mice, without alterations in dendritic complexity (Pillai et al., 2012). Fear learning can recruit new mushroomtype spines in the hippocampus (Matsuo et al., 2008), and spine density is increased in the hippocampal CA1 region $24 \mathrm{~h}$ after contextual conditioning (Pignataro et al., 2013). Depression-like behavior is also associated with spine alterations. Correlations between learned helplessness and spine synapses suggests that behavioral despair decreases as spine density increases (Hajszan et al., 2009). Additionally, anxiolytic and anti-depressant behavioral effects has been shown to be associated with enhanced neuronal activity in the hippocampus (Dagyte et al., 2010; Sah et al., 2012). The behavior phenotype observed here with $\mathrm{NgR} 2^{-/-}$ mice is distinct from that seen when NgR1 is modulated. NgR1 knockout studies have shown impaired working memory (Budel et al., 2008) and improved extinction learning (Akbik et al., 2013), but no effects on anxiety have been reported. This suggests alterations in anxiety are unique to a loss of $\mathrm{NgR} 2$.

There is evidence that NgR1 may be an activity-regulated gene, as its downregulation at mRNA level has been demonstrated after various neuronal activity inducing stimuli, such as running and kainic acid (Josephson et al., 2003; Mingorance et al., 2004; Karlsson et al., 2013). It is still not clear if NgR2 is also an activity regulated gene. In vitro studies in hippocampal neuronal cultures indicate neuronal depolarization, by $\mathrm{KCl}$ or NMDA treatment, decrease mRNA expression of NgR1-3 (Wills et al., 2012). However, an in vivo study following the time course of NgR2 expression after kainic acid challenge showed that the fast and transient downregulation of $\mathrm{NgR} 1$ by $2 \mathrm{~h}$ is then followed by upregulation of $\mathrm{NgR} 2$ and $\mathrm{NgR} 3$ in the dentate gyrus, peaking around $12 \mathrm{~h}$ post injection (Karlsson et al., 2013). These temporal differences have led to the suggestion that the immediate downregulation of $\mathrm{NgR} 1$ which enables increased plasticity is followed by increases in NgR2 and NgR3 which close the window of plasticity again (Karlsson et al., 2013). Our data suggest a more complex scenario, in which both NgR1 and NgR2 can restrict plasticity, but may have differential effects on synaptic remodeling. Further work is required to understand the temporal dynamic of this regulation. Intriguingly, an in vivo study with the stimulant amphetamine observed that both $\mathrm{NgR} 1$ and $\mathrm{NgR} 2$ protein levels were decreased in the hippocampus (Guo et al., 2013). Clearly there are certain differences between these paradigms that could be underlying differential effects seen with NgR2 expression after neuronal activity is induced. There are differences between in vitro and in vivo neuronal depolarization paradigms, and amphetamine stimulation affects the dopaminergic system, another point of difference. In the context of differential effects of NgR1 and NgR2 after neuronal activity and in modulation of spine dynamics, it is worth noting differences in ligand binding for these receptors. Of the myelin-associated inhibitors, NgR1 can interact with Nogo-A, oligodendrocyte myelin glycoprotein (OMgp) and myelin-associated glycoprotein (MAG) (Fournier et al., 2001; Domeniconi et al., 2002; Wang et al., 2002a), whilst NgR2 only binds to MAG (Venkatesh et al., 2005). NgR1 additionally has been shown to bind to the glycosaminoglycan (GAG) side chains of chrondroitin sulfate proteoglygans (CSPGs), which NgR2 does not (Dickendesher et al., 2012), and additionally, $\mathrm{NgR} 1$ and NgR2 both interact with amyloid precursor protein (APP) via interference with $\beta$-secretase 1 (BACE-1) cleavage (Park et al., 2006; Zhou et al., 2011). It is likely that other as yet unidentified ligands interact with NgR2 besides MAG, and such unknown ligands may be modulating aspects of $\mathrm{NgR} 2$ signaling in the CA1 region which influence spine dynamics. Further investigation of how regulation of $\mathrm{NgRs}$ after neuronal activity is related to binding of specific ligands may also shed light on mechanisms required for NgR2 signaling in regulating spine morphology.

We conclude that NgR2 can function to regulate mature spine morphology, and alter fear and anxiety-related, as well as depression-related, behavior. Further work will be needed to elucidate if these alterations in spines are contributing directly to modifying behavior. Furthermore, it will be important to reveal which ligands of NgR2 are involved in mediating this effect, to determine if modulating Nogo receptor 2 signaling can provide further insights into regulating anxiety-like behaviors.

\section{AUTHOR CONTRIBUTIONS}

Sarah C. Borrie, Simone B. Sartori, Nicolas Singewald, and Christine E. Bandtlow designed the experiments. Sarah C. Borrie, Simone B. Sartori, and Julian Lehmann performed the experiments. Sarah C. Borrie, Simone B. Sartori, and Anupam Sah analyzed the data. Sarah C. Borrie and Christine E. Bandtlow wrote the paper.

\section{ACKNOWLEDGMENTS}

We thank Sandra Trojer, Antje Kurz, Sabrina Riepler and Augustine Boima of Innsbruck Medical University for technical assistance, animal husbandry and genotyping support. We thank 
Dr Harm Krugers and Els Velzing of the University of Amsterdam for advice in establishing the Golgi-Cox staining. This work was supported by the Austrian Science Fund (FWF; W1206). Sarah C. Borrie and Anupam Sah were supported by the Graduate program "Signal processing in neurons" (SPIN).

\section{REFERENCES}

Akbik, F., Cafferty, W. B., and Strittmatter, S. M. (2012). Myelin associated inhibitors: a link between injury-induced and experience-dependent plasticity. Exp. Neurol. 235, 43-52. doi: 10.1016/j.expneurol.2011.06.006

Akbik, F. V., Bhagat, S. M., Patel, P. R., Cafferty, W. B. J. J., and Strittmatter, S. M. (2013). Anatomical plasticity of adult brain is titrated by Nogo Receptor 1. Neuron 77, 859-866. doi: 10.1016/j.neuron.2012.12.027

Anagnostaras, S. G., Gale, G. D., and Fanselow, M. S. (2001). Hippocampus and contextual fear conditioning: recent controversies and advances. Hippocampus 11, 8-17. doi: 10.1002/1098-1063(2001)11:1\%3C8::AIDHIPO1015\%3E3.3.CO;2-Z

Bannister, N. J., and Larkman, A. U. (1995). Dendritic morphology of CA1 pyramidal neurones from the rat hippocampus: II. Spine distributions. J. Comp. Neurol. 360, 161-171. doi: 10.1002/cne.903600112

Barrette, B., Vallieres, N., Dube, M., and Lacroix, S. (2007). Expression profile of receptors for myelin-associated inhibitors of axonal regeneration in the intact and injured mouse central nervous system. Mol. Cell. Neurosci. 34, 519-538. doi: 10.1016/j.mcn.2006.12.004

Bayés, A., Collins, M. O., Croning, M. D. R., Van De Lagemaat, L. N., Choudhary, J. S., and Grant, S. G. N. (2012). Comparative study of human and mouse postsynaptic proteomes finds high compositional conservation and abundance differences for key synaptic proteins. PLOS ONE 7:e46683. doi: 10.1371/journal.pone.0046683

Beltrán-Campos, V., Prado-Alcalá, R. A., León-Jacinto, U., Aguilar-Vázquez, A., Quirarte, G. L., Ramírez-Amaya, V., et al. (2011). Increase of mushroom spine density in CAl apical dendrites produced by water maze training is prevented by ovariectomy. Brain Res. 1369, 119-130. doi: 10.1016/j.brainres.2010.10.105

Blanchard, R. J., and Blanchard, D. C. (1969). Passive and active reactions to feareliciting stimuli. J. Comp. Physiol. Psychol. 68, 129-135. doi: 10.1037/h0027676

Budel, S., Padukkavidana, T., Liu, B. P., Feng, Z., Hu, F., Johnson, S., et al. (2008). Genetic variants of Nogo-66 receptor with possible association to schizophrenia block myelin inhibition of axon growth. J. Neurosci. 28, 13161-13172. doi: 10.1523/JNEUROSCI.3828-08.2008

Chakravarthy, S., Saiepour, M. H., Bence, M., Perry, S., Hartman, R., Couey, J. J., et al. (2006). Postsynaptic TrkB signaling has distinct roles in spine maintenance in adult visual cortex and hippocampus. Proc. Natl. Acad. Sci. U.S.A. 103, 1071-1076. doi: 10.1073/pnas.0506305103

Champagne, D. L., Bagot, R. C., Van Hasselt, F., Ramakers, G., Meaney, M. J., De Kloet, E. R., et al. (2008). Maternal care and hippocampal plasticity: evidence for experience-dependent structural plasticity, altered synaptic functioning, and differential responsiveness to glucocorticoids and stress. J. Neurosci. 28, 6037-6045. doi: 10.1523/JNEUROSCI.0526-08.2008

Chourbaji, S., Pfeiffer, N., Dormann, C., Brandwein, C., Fradley, R., Sheardown, M., et al. (2010). The suitability of $129 \mathrm{SvEv}$ mice for studying depressive-like behaviour: both males and females develop learned helplessness. Behav. Brain Res. 211, 105-110. doi: 10.1016/j.bbr.2010.03.019

Cryan, J. F., and Holmes, A. (2005). The ascent of mouse: advances in modelling human depression and anxiety. Nat. Rev. Drug Discov. 4, 775-790. doi: $10.1038 / \mathrm{nrd} 1825$

Dagyte, G., Trentani, A., Postema, F., Luiten, P. G., Den Boer, J. A., Gabriel, C., et al. (2010). The novel antidepressant agomelatine normalizes hippocampal neuronal activity and promotes neurogenesis in chronically stressed rats. CNS Neurosci. Ther. 16, 195-207. doi: 10.1111/j.1755-5949.2009. 00125.x

Delekate, A., Zagrebelsky, M., Kramer, S., Schwab, M. E., and Korte, M. (2011). NogoA restricts synaptic plasticity in the adult hippocampus on a fast time scale. Proc. Natl. Acad. Sci. U.S.A. 108, 2569-2574. doi: 10.1073/pnas.1013322108

Dickendesher, T. L., Baldwin, K. T., Mironova, Y. A., Koriyama, Y., Raiker, S. J., Askew, K. L., et al. (2012). NgR1 and NgR3 are receptors for chondroitin sulfate proteoglycans. Nat. Neurosci. 15, 703-712. doi: 10.1038/nn.3070

Domeniconi, M., Cao, Z., Spencer, T., Sivasankaran, R., Wang, K., Nikulina, E., et al. (2002). Myelin-associated glycoprotein interacts with the Nogo66 receptor to inhibit neurite outgrowth. Neuron 35, 283-290. doi: 10.1016/S08966273(02)00770-5

Donohue, H. S., Gabbott, P. L. A., Davies, H. A., Rodríguez, J. J., Cordero, M. I., Sandi, C., et al. (2006). Chronic restraint stress induces changes in synapse morphology in stratum lacunosum-moleculare CA1 rat hippocampus: a stereological and three-dimensional ultrastructural study. Neuroscience 140, 597-606. doi: 10.1016/j.neuroscience.2006.02.072

Fanselow, M. S. (1980). Conditioned and unconditional components of post-shock freezing. Pavlov. J. Biol. Sci. 15, 177-182.

Fournier, A. E., Grandpre, T., and Strittmatter, S. M. (2001). Identification of a receptor mediating Nogo-66 inhibition of axonal regeneration. Nature 409, 341-346. doi: 10.1038/35053072

Franklin, K. B., and Paxinos, G. (2008). The Mouse Brain in Stereotaxic Coordinates. San Diego, CA: Elsevier Academic Press.

Funahashi, S., Hasegawa, T., Nagano, A., and Sato, K. (2008). Differential expression patterns of messenger RNAs encoding Nogo receptors and their ligands in the rat central nervous system. J. Comp. Neurol. 506, 141-160. doi: $10.1002 /$ cne. 21541

Görlich, A., Zimmermann, A. M., Schober, D., Böttcher, R. T., Sassoé-Pognetto, M., Friauf, E., et al. (2012). Preserved morphology and physiology of excitatory synapses in profilin1-deficient mice. PLOS ONE 7:e30068. doi: 10.1371/journal.pone.0030068

Guo, M. L., Xue, B., Jin, D. Z., Mao, L. M., and Wang, J. Q. (2013). Dynamic downregulation of Nogo receptor expression in the rat forebrain by amphetamine. Neurochem. Int. 63, 195-200. doi: 10.1016/j.neuint.2013.06.006

Hajszan, T., Dow, A., Warner-Schmidt, J. L., Szigeti-Buck, K., Sallam, N. L., Parducz, A., et al. (2009). Remodeling of hippocampal spine synapses in the rat learned helplessness model of depression. Biol. Psychiatry 65, 392-400. doi: 10.1016/j.biopsych.2008.09.031

Hensch, T. K. (2004). Critical period regulation. Annu. Rev. Neurosci. 27, 549-579. doi: 10.1146/annurev.neuro.27.070203.144327

Holtmaat, A. J. G. D., Trachtenberg, J. T., Wilbrecht, L., Shepherd, G. M., Zhang, X., Knott, G. W., et al. (2005). Transient and persistent dendritic spines in the neocortex in vivo. Neuron 45, 279-291. doi: 10.1016/j.neuron.2005.01.003

Holtmaat, A., Wilbrecht, L., Knott, G. W., Welker, E., and Svoboda, K. (2006). Experience-dependent and cell-type-specific spine growth in the neocortex. Nature 441, 979-983. doi: 10.1038/nature04783

Hunsaker, M. R., and Kesner, R. P. (2008). Dissociations across the dorsal-ventral axis of CA3 and CA1 for encoding and retrieval of contextual and auditory-cued fear. Neurobiol. Learn. Mem. 89, 61-69. doi: 10.1016/j.nlm.2007.08.016

Hunsaker, M. R., Tran, G. T., and Kesner, R. P. (2009). A behavioral analysis of the role of CA3 and CA1 subcortical efferents during classical fear conditioning. Behav. Neurosci. 123, 624-630. doi: 10.1037/a0015455

Josephson, A., Trifunovski, A., Scheele, C., Widenfalk, J., Wahlestedt, C., Brene, S., et al. (2003). Activity-induced and developmental downregulation of the Nogo receptor. Cell Tissue Res. 311, 333-342. doi: 10.1007/s00441002-0695-8

Kajiwara, R., Wouterlood, F. G., Sah, A., Boekel, A. J., Baks-Te Bulte, L. T., and Witter, M. P. (2008). Convergence of entorhinal and CA3 inputs onto pyramidal neurons and interneurons in hippocampal area CA1-an anatomical study in the rat. Hippocampus 18, 266-280. doi: 10.1002/hipo.20385

Karlen, A., Karlsson, T. E., Mattsson, A., Lundstromer, K., Codeluppi, S., Pham, T. M., et al. (2009). Nogo receptor 1 regulates formation of lasting memories. Proc. Natl. Acad. Sci. U.S.A. 106, 20476-20481. doi: 10.1073/pnas.0905390106

Karlsson, T. E., Koczy, J., Brené, S., Olson, L., and Josephson, A. (2013). Differential conserted activity induced regulation of nogo receptors (13), LOTUS and nogo mRNA in mouse brain. PLoS ONE 8:e60892. doi: 10.1371/journal.pone.0060892

Laurén, J., Airaksinen, M. S., Saarma, M., and Timmusk, T. (2003). Two novel mammalian Nogo receptor homologs differentially expressed in the central and peripheral nervous systems. Mol. Cell. Neurosci. 24, 581-594. doi: 10.1016/S1044-7431(03)00199-4

Lee, H., Raiker, S. J., Venkatesh, K., Geary, R., Robak, L. A., Zhang, Y., et al. (2008). Synaptic function for the Nogo-66 receptor NgR1: regulation of dendritic spine morphology and activity-dependent synaptic strength. J. Neurosci. 28, 2753-2765. doi: 10.1523/JNEUROSCI.5586-07.2008

Lendvai, B., Stern, E. A., Chen, B., and Svoboda, K. (2000). Experience-dependent plasticity of dendritic spines in the developing rat barrel cortex in vivo. Nature 404, 876-881. doi: 10.1038/35009107 
Leslie, J. H., and Nedivi, E. (2011). Activity-regulated genes as mediators of neural circuit plasticity. Prog. Neurobiol. 94, 223-237. doi: 10.1016/j.pneurobio.2011. 05.002

Leuner, B., Falduto, J., and Shors, T. J. (2003). Associative memory formation increases the observation of dendritic spines in the hippocampus. J. Neurosci. 23, 659-665.

Lin, Y. C., and Koleske, A. J. (2010). Mechanisms of synapse and dendrite maintenance and their disruption in psychiatric and neurodegenerative disorders. Annu. Rev. Neurosci. 33, 349-378. doi: 10.1146/annurev-neuro-060909-153204

Liu, B. P., Fournier, A., Grandpre, T., and Strittmatter, S. M. (2002). Myelinassociated glycoprotein as a functional ligand for the Nogo-66 receptor. Science 297, 1190-1193. doi: 10.1126/science.1073031

Luikart, B. W., Nef, S., Virmani, T., Lush, M. E., Liu, Y., Kavalali, E. T., et al. (2005). TrkB has a cell-autonomous role in the establishment of hippocampal Schaffer collateral synapses. J. Neurosci. 25, 3774-3786. doi: 10.1523/JNEUROSCI.004105.2005

Majewska, A., and Sur, M. (2003). Motility of dendritic spines in visual cortex in vivo: changes during the critical period and effects of visual deprivation. Proc. Natl. Acad. Sci. U.S.A. 100, 16024-16029. doi: 10.1073/pnas.2636949100

Matsuo, N., Reijmers, L., and Mayford, M. (2008). Spine-type-specific recruitment of newly synthesized AMPA receptors with learning. Science 319, 1104-1107. doi: 10.1126/science.1149967

Matsuzaki, M., Ellis-Davies, G. C., Nemoto, T., Miyashita, Y., Iino, M., and Kasai, H. (2001). Dendritic spine geometry is critical for AMPA receptor expression in hippocampal CA1 pyramidal neurons. Nat. Neurosci. 4, 1086-1092. doi: $10.1038 / \mathrm{nn} 736$

McGee, A. W., Yang, Y., Fischer, Q. S., Daw, N. W., and Strittmatter, S. M. (2005). Experience-driven plasticity of visual cortex limited by myelin and Nogo receptor. Science 309, 2222-2226. doi: 10.1126/science.1114362

Megías, M., Emri, Z., Freund, T. F., and Gulyás, A. I. (2001). Total number and distribution of inhibitory and excitatory synapses on hippocampal CA1 pyramidal cells. Neuroscience 102, 527-540. doi: 10.1016/S0306-4522(00)00496-6

Mingorance, A., Fontana, X., Sole, M., Burgaya, F., Urena, J. M., Teng, F. Y., et al. (2004). Regulation of Nogo and Nogo receptor during the development of the entorhino-hippocampal pathway and after adult hippocampal lesions. Mol. Cell. Neurosci. 26, 34-49. doi: 10.1016/j.mcn.2004.01.001

Miyakawa, T., Yared, E., Pak, J. H., Huang, F. L., Huang, K. P., and Crawley, J. N. (2001). Neurogranin null mutant mice display performance deficits on spatial learning tasks with anxiety related components. Hippocampus 11, 763-775. doi: 10.1002/hipo.1092

Moser, M. B., Trommald, M., and Andersen, P. (1994). An increase in dendritic spine density on hippocampal CA1 pyramidal cells following spatial learning in adult rats suggests the formation of new synapses. Proc. Natl. Acad. Sci. U.S.A. 91, 12673-12675. doi: 10.1073/pnas.91.26.12673

Moser, M. B., Trommald, M., Egeland, T., and Andersen, P. (1997). Spatial training in a complex environment and isolation alter the spine distribution differently in rat CA1 pyramidal cells. J. Comp. Neurol. 380, 373-381.

Nordgren, M., Karlsson, T., Svensson, M., Koczy, J., Josephson, A., Olson, L., et al. (2013). Orchestrated regulation of Nogo Receptors, Lotus, AMPA receptors and BDNF in an ECT model suggests opening and closure of a window of synaptic plasticity. PLoS ONE 8:e78778. doi: 10.1371/journal.pone.0078778

Park, J. H., Gimbel, D. A., Grandpre, T., Lee, J. K., Kim, J. E., Li, W., et al. (2006). Alzheimer precursor protein interaction with the Nogo-66 receptor reduces amyloid-beta plaque deposition. J. Neurosci. 26, 1386-1395. doi: 10.1523/JNEUROSCI.3291-05.2006

Pawlak, R., Rao, B. S., Melchor, J. P., Chattarji, S., McEwen, B., and Strickland, S. (2005). Tissue plasminogen activator and plasminogen mediate stress-induced decline of neuronal and cognitive functions in the mouse hippocampus. Proc. Natl. Acad. Sci. U.S.A. 102, 18201-18206. doi: 10.1073/pnas.0509232102

Paylor, R., Spencer, C. M., Yuva-Paylor, L. A., and Pieke-Dahl, S. (2006). The use of behavioral test batteries, II: effect of test interval. Physiol. Behav. 87, 95-102. doi: 10.1016/j.physbeh.2005.09.002

Perez-Cruz, C., Nolte, M. W., Van Gaalen, M. M., Rustay, N. R., Termont, A., Tanghe, A., et al. (2011). Reduced spine density in specific regions of CA1 pyramidal neurons in two transgenic mouse models of Alzheimer's disease. J. Neurosci. 31, 3926-3934. doi: 10.1523/JNEUROSCI.6142-10.2011

Phillips, R. G., and Ledoux, J. E. (1992). Differential contribution of amygdala and hippocampus to cued and contextual fear conditioning. Behav. Neurosci. 106, 274-285. doi: 10.1037/0735-7044.106.2.274
Pignataro, A., Middei, S., Borreca, A., and Ammassari-Teule, M. (2013). Indistinguishable pattern of amygdala and hippocampus rewiring following tone or contextual fear conditioning in C57BL/6 mice. Front. Behav. Neurosci. 7:156. doi: 10.3389/fnbeh.2013.00156

Pillai, A. G., De Jong, D., Kanatsou, S., Krugers, H., Knapman, A., Heinzmann, J.M., et al. (2012). Dendritic morphology of hippocampal and amygdalar neurons in adolescent mice is resilient to genetic differences in stress reactivity. PLoS ONE 7:e38971. doi: 10.1371/journal.pone.0038971

Raiker, S. J., Lee, H., Baldwin, K. T., Duan, Y., Shrager, P., and Giger, R. J. (2010). Oligodendrocyte-myelin glycoprotein and Nogo negatively regulate activity-dependent synaptic plasticity. J. Neurosci. 30, 12432-12445. doi: 10.1523/JNEUROSCI.0895-10.2010

Rauskolb, S., Zagrebelsky, M., Dreznjak, A., Deogracias, R., Matsumoto, T., Wiese, S., et al. (2010). Global deprivation of brain-derived neurotrophic factor in the CNS reveals an area-specific requirement for dendritic growth. J. Neurosci. 30, 1739-1749. doi: 10.1523/JNEUROSCI.5100-09.2010

Rezayat, M., Roohbakhsh, A., Zarrindast, M. R., Massoudi, R., and Djahanguiri, B. (2005). Cholecystokinin and GABA interaction in the dorsal hippocampus of rats in the elevated plus-maze test of anxiety. Physiol. Behav. 84, 775-782. doi: 10.1016/j.physbeh.2005.03.002

Sah, A., Schmuckermair, C., Sartori, S. B., Gaburro, S., Kandasamy, M., Irschick, R., et al. (2012). Anxiety- rather than depression-like behavior is associated with adult neurogenesis in a female mouse model of higher trait anxiety- and comorbid depression-like behavior. Transl. Psychiatry 2, e171. doi: 10.1038/tp.2012.94 Sartori, S. B., Hauschild, M., Bunck, M., Gaburro, S., Landgraf, R., and Singewald, N. (2011). Enhanced fear expression in a psychopathological mouse model of trait anxiety: pharmacological interventions. PLoS ONE 6:e16849. doi: 10.1371/journal.pone.0016849

Sanders, J., Cowansage, K., Baumgärtel, K., and Mayford, M. (2012). Elimination of dendritic spines with long-term memory is specific to active circuits. J. Neurosci. 32, 12570-12578. doi: 10.1523/JNEUROSCI.1131-12.2012

Schmuckermair, C., Gaburro, S., Sah, A., Landgraf, R., Sartori, S. B., and Singewald, N. (2013). Behavioral and neurobiological effects of deep brain stimulation in a mouse model of high anxiety- and depression-like behavior. Neuropsychopharmacology 38, 1234-1244. doi: 10.1038/npp.2013.21

Sheng, M., and Hoogenraad, C. C. (2007). The postsynaptic architecture of excitatory synapses: a more quantitative view. Annu. Rev. Biochem. 76, 823-847. doi: 10.1146/annurev.biochem.76.060805.160029

Shors, T. J., Chua, C., and Falduto, J. (2001). Sex differences and opposite effects of stress on dendritic spine density in the male versus female hippocampus. J. Neurosci. 21, 6292-6297.

Spruston, N., and McBain, C. (2007). "Structural and functional properties of hippocampal neurons," in The hippocampus Book, eds P. Andersen, R. Morris D. Amaral, T. Bliss, and J. O’Keefe (New York, NY: Oxford University Press), 133-201.

Tan, L. A., Al Chawaf, A., Vaccarino, F. J., Boutros, P. C., and Lovejoy, D. A. (2011). Teneurin C-terminal associated peptide (TCAP)-1 modulates dendritic morphology in hippocampal neurons and decreases anxiety-like behaviors in rats. Physiol. Behav. 104, 199-204. doi: 10.1016/j.physbeh.2011.03.015

Tashiro, A., and Yuste, R. (2004). Regulation of dendritic spine motility and stability by Racl and Rho kinase: evidence for two forms of spine motility. Mol. Cell. Neurosci. 26, 429-440. doi: 10.1016/j.mcn.2004.04.001

Trachtenberg, J. T., Chen, B. E., Knott, G. W., Feng, G., Sanes, J. R., Welker, E., et al. (2002). Long-term in vivo imaging of experience-dependent synaptic plasticity in adult cortex. Nature 420, 788-794. doi: 10.1038/nature01273

Venkatesh, K., Chivatakarn, O., Lee, H., Joshi, P. S., Kantor, D. B., Newman, B. A., et al. (2005). The Nogo-66 receptor homolog NgR2 is a sialic acid-dependent receptor selective for myelin-associated glycoprotein. J. Neurosci. 25, 808-822. doi: 10.1523/JNEUROSCI.4464-04.2005

Vyas, A., Mitra, R., Shankaranarayana Rao, B. S., and Chattarji, S. (2002). Chronic stress induces contrasting patterns of dendritic remodeling in hippocampal and amygdaloid neurons. J. Neurosci. 22, 6810-6818.

Wang, G., Cheng, Y., Gong, M., Liang, B., Zhang, M., Chen, Y., et al. (2013). Systematic correlation between spine plasticity and the anxiety/depression-like phenotype induced by corticosterone in mice. Neuroreport 24, 682-687. doi: 10.1097/WNR.0b013e32836384db

Wang, K. C., Koprivica, V., Kim, J. A., Sivasankaran, R., Guo, Y., Neve, R. L., et al. (2002a). Oligodendrocyte-myelin glycoprotein is a Nogo receptor ligand that inhibits neurite outgrowth. Nature 417, 941-944. doi: 10.1038/nature00867 
Wang, X., Chun, S. J., Treloar, H., Vartanian, T., Greer, C. A., and Strittmatter, S. M. (2002b). Localization of Nogo-A and Nogo-66 receptor proteins at sites of axon-myelin and synaptic contact. J. Neurosci. 22, 5505-5515.

Wills, Z. P., Mandel-Brehm, C., Mardinly, A. R., McCord, A. E., Giger, R. J., and Greenberg, M. E. (2012). The Nogo receptor family restricts synapse number in the developing hippocampus. Neuron 73, 466-481. doi: 10.1016/j.neuron.2011.11.029

Wittmann, W., Schunk, E., Rosskothen, I., Gaburro, S., Singewald, N., Herzog, H., et al. (2009). Prodynorphin-derived peptides are critical modulators of anxiety and regulate neurochemistry and corticosterone. Neuropsychopharmacology 34, 775-785. doi: 10.1038/npp.2008.142

Wörter, V., Schweigreiter, R., Kinzel, B., Mueller, M., Barske, C., Böck, G., et al. (2009). Inhibitory activity of myelin-associated glycoprotein on sensory neurons is largely independent of $\mathrm{NgR} 1$ and $\mathrm{NgR} 2$ and resides within Ig-Like domains 4 and 5. PLoS ONE 4:e5218. doi: 10.1371/journal.pone.0005218

Yang, E. J., Lin, E. W., and Hensch, T. K. (2012). Critical period for acoustic preference in mice. Proc. Natl. Acad. Sci. U.S.A. 109(Suppl. 2), 17213-17220. doi: 10.1073/pnas.1200705109

Zagrebelsky, M., Schweigreiter, R., Bandtlow, C. E., Schwab, M. E., and Korte, M. (2010). Nogo-A stabilizes the architecture of hippocampal neurons. J. Neurosci. 30, 13220-13234. doi: 10.1523/JNEUROSCI.1044-10.2010
Zhou, X., Hu, X., He, W., Tang, X., Shi, Q., Zhang, Z., et al. (2011). Interaction between amyloid precursor protein and Nogo receptors regulates amyloid deposition. FASEB J. 25, 3146-3156. doi: 10.1096/fj.11-184325

Conflict of Interest Statement: The authors declare that the research was conducted in the absence of any commercial or financial relationships that could be construed as a potential conflict of interest.

Received: 25 January 2014; accepted: 25 April 2014; published online: 15 May 2014 Citation: Borrie SC, Sartori SB, Lehmann J, Sah A, Singewald N and Bandtlow CE (2014) Loss of Nogo receptor homolog NgR2 alters spine morphology of CA1 neurons and emotionality in adult mice. Front. Behav. Neurosci. 8:175. doi: 10.3389/fnbeh. 2014.00175

This article was submitted to the journal Frontiers in Behavioral Neuroscience. Copyright (c) 2014 Borrie, Sartori, Lehmann, Sah, Singewald and Bandtlow. This is an open-access article distributed under the terms of the Creative Commons Attribution License (CC BY). The use, distribution or reproduction in other forums is permitted, provided the original author(s) or licensor are credited and that the original publication in this journal is cited, in accordance with accepted academic practice. No use, distribution or reproduction is permitted which does not comply with these terms. 